\title{
Casticin inhibits interleukin-1 $\beta$-induced ICAM-1 and MUC5AC expression by blocking NF-KB, PI3K-Akt, and MAPK signaling in human lung epithelial cells
}

\author{
Chian-Jiun Liou ${ }^{1,2}$ and Wen-Chung Huang ${ }^{2,3}$ \\ ${ }^{1}$ Department of Nursing, Chang Gung University of Science and Technology, Taoyuan City, 33303, Taiwan \\ ${ }^{2}$ Division of Allergy, Asthma, and Rheumatology, Department of Pediatrics, Chang Gung Memorial Hospital, Taoyuan City, \\ 33303, Taiwan \\ ${ }^{3}$ Graduate Institute of Health Industry Technology, Research Center for Food and Cosmetic Safety, and Research Center \\ for Chinese Herbal Medicine, College of Human Ecology, Chang Gung University of Science and Technology, Taoyuan City, \\ 33303, Taiwan
}

Correspondence to: Wen-Chung Huang, email: wchuang@mail.cgust.edu.tw

Keywords: casticin, ICAM-1, Interleukin-1 $\beta, M A P K, N F-\kappa B$

Received: June 30, $2017 \quad$ Accepted: August 27, 2017

Published: September 15, 2017

Copyright: Liou et al. This is an open-access article distributed under the terms of the Creative Commons Attribution License 3.0 (CC BY 3.0), which permits unrestricted use, distribution, and reproduction in any medium, provided the original author and source are credited.

\section{ABSTRACT}

The compound casticin, isolated from Vitex rotundifolia, exerts anti-inflammatory effects and causes apoptosis of cancer cells. In this study, we explored the antiinflammatory effects of casticin and modulation of cyclooxygenase (COX)-2, intercellular adhesion molecule 1 (ICAM-1), and mucin 5AC (MUC5AC) expression in interleukin-1 $\beta$ (IL-1 $\beta$ )-activated A549 human pulmonary epithelial cells. A549 cells were treated with various concentrations of casticin (5-20 $\mu \mathrm{M})$, and an inflammatory response was triggered with interleukin (IL)-1ß cytokines. Casticin decreased levels of IL-6, tumor necrosis factor $\mathrm{a}$, and IL-8 and suppressed COX-2 expression and prostaglandin E2 production. It also reduced MUC5AC, proinflammatory cytokine, and chemokine gene expression and inhibited ICAM-1 expression for monocyte adhesion in IL-1 $\beta$-stimulated A549 cells. In addition, casticin inhibited phosphorylation of Akt, phosphatidylinositol 3-kinase (PI3K), and mitogen-activated protein kinase (MAPK) and blocked nuclear transcription factor kappa-B (NF-kB) subunit p65 protein translocation into the nucleus. Co-culture of NF-kB, MAPK, and PI3K inhibitors with casticin also led to more significantly suppressed ICAM-1 expression in inflammatory A549 cells. These results provide evidence that casticin has an anti-inflammatory effect by blocking proinflammatory cytokine, chemokine, and ICAM1 expression via suppression of the PI3K/Akt, NF-KB, and MAPK signaling pathways in IL-1 $\beta$-stimulated inflammatory pulmonary epithelial cells.

\section{INTRODUCTION}

The inflammatory response of airways is a physical danger signal and defense mechanism against microbe infection or injurious airborne particles [1]. Inflammatory pulmonary diseases include asthma, chronic obstructive pulmonary disease (COPD), and bacterial or viral pneumonia $[2,3]$. These reactive airway diseases can lead to sputum production, coughing, and wheezing, and the airway of patients also may be stimulated to constrict, with excessive mucus secretion leading to dyspnea or suffocation and death [4]. With a bacterial or viral infection, activation of macrophages and T cells of airways occurs, and more interleukin (IL)-1 $\beta$ can be detected in inflammatory diseases of the airways [5]. It had been previously found that influenza A virus major targeted epithelial cells of airway and lung to induce airway inflammatory and caused the damage of lung tissue. Influenza A virus could activate innate immune to secret IL-1 $\beta$ for caused airways damage [6]. Recent studies have also found that lung epithelial cells can release excessive proinflammatory cytokines, including IL- $1 \beta$ and tumor necrosis factor $\alpha$ (TNF- $\alpha$ ), triggering a severe immuneinflammatory response in asthmatic patients [7]. In IL-1 
receptor knockout mice, neutrophil infiltration of the lungs is significantly decreased in lipopolysaccharide (LPS)induced lung injury, and these animals show a suppressed airway hyperresponse compared with wild-type asthmatic mice [8]. Anti-inflammatories, such as non-steroidal antiinflammatory drugs, could attenuate airway inflammatory disease $[9,10]$. Cyclooxygenase 2 (COX-2) breaks down arachidonic acid to produce prostaglandins, which can increase inflammation, fever, and pain [9]. Non-steroidal anti-inflammatory drugs decrease COX-2 activity and reduce inflammation and fever in these patients $[11,12]$. Celecoxib is a COX-2 inhibitor that ameliorates newborn hyperoxic lung injury in mice and decreases levels of prostaglandin E2 $\left(\mathrm{PGE}_{2}\right)$ to suppress lung inflammation in asthma patients $[13,14]$. Hence, blocking IL-1 $\beta$ levels could ameliorate the lung inflammatory response in pulmonary disease patients.

A previous study found that inflammatory lung epithelial cells express the IL-1 receptor [15]. IL-1 $\beta$ binds the IL-1 receptor, inducing activity of inflammatory signaling pathways in lung epithelial cells, leading to the release of proinflammatory cytokines, chemokines, and inflammatory mediators. Nuclear transcription factor kappa-B (NF- $\kappa \mathrm{B})$ is an important inflammation signaling molecule in IL-1 $\beta$-stimulated lung epithelial cells [16]. When inflammatory molecules stimulate IкB phosphorylation, $\mathrm{NF}-\kappa \mathrm{B}$ subunits p65 and p50 are also translocated into the nucleus to trigger expression of inflammation-associated cytokines and mediator genes $[17,18]$. IL-1 $\beta$-stimulated lung epithelial cells also activate the mitogen-activated protein kinase (MAPK) and phosphatidylinositol 3-kinase (PI3K) signaling pathways to exacerbate the inflammatory response [19]. In turn, inflammatory lung epithelial cells release more chemokines to attract leukocytes, and the surface of lung epithelial cells expresses intercellular adhesion molecule 1 (ICAM-1) to attract macrophage, neutrophil, or eosinophil infiltration into the lung tissue $[20,21]$. Thus, reducing ICAM-1 expression in lung epithelial cells also might ameliorate respiratory inflammatory diseases.

Recent studies found that some bacterial infection could increase IL-1 $\beta$ production to activate NLRP3 inflammasome for caused community-acquired pneumonia [22]. Streptococcus pneumoniae could destroy the effect of plasma membrane of lung epithelial cells for interfered $\mathrm{K}^{+}$efflux by activation of the NLRP3 inflammasome [23]. Activated immune cells released IL-1 $\beta$ to cause inflammatory response and increase the body temperature to attenuate microbial activity. The blood and sputum of asthma and COPD patients found that IL-1 $\beta$ gene expression was significantly higher than healthy people [24]. Moreover, IL-1 $\beta$-related signaling pathway also significantlly activated in the lung of asthma and COPD patients [25]. Hence, to reduce the IL-1 $\beta$ levels and inflammation of local lungs could improve the incidence of asthma and COPD. Furthermore, obese mice treated with IL-1 $\beta$ antagonist could attenuate airway hyperresponsiveness and inflammtion of lung [26]. Breast and lung cancer patients also found that could detect more high IL- $1 \beta$ levels compared to health adult. Clinical treatment reduced IL-1 $\beta$ levels of lung would have an opportunity to improve inflammation and the development of lung cancer [27].

Vitex rotundifolia L. grows in the countryside of China and Taiwan, and its fruit has been used to treat inflammation, gastroenteritis, and headaches in traditional Chinese medicine [28]. Casticin, isolated from $V$. rotundifolia, has been reported to have anti-tumor effects in vitro [29]. Previously, we found that casticin could suppress the inflammatory effect by blocking the NF- $\kappa \mathrm{B}$ and MAPK pathways in LPS-induced RAW264.7 macrophage cells [30]. Casticin also decreases the levels of eotaxin and reduces eosinophil migration in IL-1 $\beta$ stimulated A549 human lung epithelial cells [28].

In this study, we evaluated the anti-inflammatory effect of casticin and explored the mechanism of involvement of the NF-kB, PI3k/Akt, and MAPK signaling pathways in IL-1 $\beta$-stimulated A549 cells.

\section{RESULTS}

\section{Casticin inhibited proinflammatory cytokine and

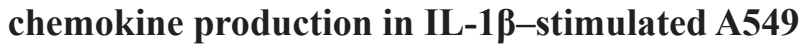 cells}

The cytotoxicity of casticin in A549 and H460 cells was determined by MTT assay.

Casticin did not significantly affect cell cytotoxicity at doses $\leq 20 \mu \mathrm{M}$, and all experiments used casticin from 5-20 $\mu \mathrm{M}$ (Supplementary Figure 1A). Next, cells were treated with different doses of IL-1 $\beta(0.5-5 \mathrm{ng} / \mathrm{ml})$ for 24 h. A549 cells could significantly increase the levels of IL-6 and IL-8 in a dose-dependent manner compared with untreated cells (Supplementary Figure 1B, 1C). We found that IL-1 $\beta$-stimulated H460 did not significantly increase IL- 6 and IL-8 productions. Furthermore, casticin could decrease the levels of IL-6 and IL-8 without IL-1 $\beta$-stimulated H460 cells (Supplementary Figure 1D, 1E). Hence, A549 cells were used to evalute the anti-inflammatory effects of casticin. Casticin had a dose-dependent inhibitory effect on levels of IL-6, TNF- $\alpha$, IL-8 (IL-6: $5 \mu \mathrm{M}$ casticin, $681.86 \pm 109.45$ pg/ $\mathrm{ml}, p=0.34 ; 10 \mu \mathrm{M}$ casticin, $516.05 \pm 83.03 \mathrm{pg} / \mathrm{ml}$, $p<0.05 ; 20 \mu \mathrm{M}$ casticin, $263.91 \pm 54.85 \mathrm{pg} / \mathrm{ml}, p<0.01$; vs. IL-1 $\beta$ alone, $717.21 \pm 83.08 \mathrm{pg} / \mathrm{ml})(\mathrm{TNF}-\alpha: 5 \mu \mathrm{M}$ casticin, $377.92 \pm 35.90 \mathrm{pg} / \mathrm{ml}, p=0.22 ; 10 \mu \mathrm{M}$ casticin, $247.29 \pm 35.86 \mathrm{pg} / \mathrm{ml}, p<0.01 ; 20 \mu \mathrm{M}$ casticin, 136.70 $\pm 40.97 \mathrm{pg} / \mathrm{ml}, p<0.01$; vs. IL- $\beta$ alone, $439.59 \pm 47.50$ $\mathrm{pg} / \mathrm{ml}$ ), and casticin also could decrease the levels of IL-8, CCL5, and MCP-1 in IL-1 $\beta$-stimulated A549 cells (Figure 1). We also evaluated the gene expression of proinflammatory cytokines and chemokines by real-time 
PCR and found that casticin significantly suppressed IL-1 $\beta$, IL-6, TNF- $\alpha$, IL-8, CCL5, MCP-1, IL-17F, and CCL26 (Figure 2). However, it did not significantly modulate IL-17A, CCL11, CCL17, or CCL24 gene expression. Additionally, casticin inhibited MUC5AC, $\mathrm{C} / \mathrm{EBP} \beta$, and epidermal growth factor receptor (EGFR), but $\mathrm{C} / \mathrm{EBP} \alpha$ did not show decreased gene expression in A549 cells.

\section{Casticin suppressed COX-2 expression in IL-1 $\beta$ - stimulated A549 cells}

When A549 cells were treated with various concentrations of casticin and then stimulated with IL-1 $\beta$, casticin significantly suppressed COX-2 protein expression compared with IL- $1 \beta$-stimulated cells (Figure 3A, 3B). Real-time PCR analysis revealed that casticin also decreased COX-2 gene expression in a concentration-dependent manner (Figure 3C). In addition, we found that casticin significantly reduced the level of $\mathrm{PGE}_{2}$ ( $5 \mu \mathrm{M}$ casticin, $4.74 \pm 0.68 \mathrm{ng} / \mathrm{ml}, p<0.05 ; 10 \mu \mathrm{M}$ casticin, $2.94 \pm 0.55 \mathrm{ng} / \mathrm{ml}, p<0.01 ; 20 \mu \mathrm{M}$ casticin, $1.77 \pm 0.62 \mathrm{ng} / \mathrm{ml}$, $p<0.01$; vs. IL-1 $\beta$ alone, $7.25 \pm 0.53 \mathrm{ng} / \mathrm{ml}$ ) (Figure 3D).

\section{Casticin suppressed ICAM-1 expression in A549 cells}

The ICAM-1 protein assay showed that casticin significantly reduced ICAM-1 expression (Figure 4A, 4B) and suppressed soluble ICAM-1 release into culture medium compared with IL-1 $\beta$-stimulated A549 cells (Figure 4C). Real-time PCR investigation showed that casticin significantly inhibited ICAM-1 gene expression in A549 cells (Figure 4D). Casticin also significantly suppressed luciferase activity by blocking ICAM-1 promoter activity (Figure 4E). We additionally evaluated whether casticin could suppress the ability of monocyte THP-1 cells to adhere to IL-1 $\beta$-stimulated A549 cells. Pretreatment with casticin decreased adhesion of THP-1 cells to A549 cells (Figure 5F, 5G).

\section{Casticin suppressed ICAM-1 and Muc5AC expression in A549 cells treated with an IL-1 receptor antagonist}

IL-1 $\beta$-stimulated A549 cells showed increased IL-1 $\beta$ gene expression (Figure 2), suggesting that these cells have IL-1 receptor activity and expression. Previously, it was shown that IL-1 $\beta$ could stimulate IL-1 expression and that the IL-1 receptor antagonist (IL-1RA) could block the IL-1 $\beta$ signaling pathway [31]. Thus, IL-1RA would be expected to lead to decreased ICAM-1 and MUC5AC gene expression in IL- $1 \beta$-stimulated A549 cells, as we found (Figure $5 \mathrm{~A}, 5 \mathrm{~B}$ ). We also found that casticin could more significantly decrease ICAM-1 and MUC5AC gene expression when IL-1 $\beta$-stimulated A549 cells were treated with IL-1RA. In addition, pretreatment with casticin even further suppressed the adhesion of THP-1 cells to IL-1 $\beta / \mathrm{IL}-1 \mathrm{RA}-$ treated A549 cells (Figure 5C, 5D).

\section{Inhibition by casticin of inflammatory signaling

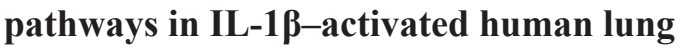 epithelial cells}

Casticin suppressed proinflammatory cytokine, chemokine, and ICAM-1 expression. Thus, we also evaluated whether casticin suppressed the NF- $\mathrm{B}$,
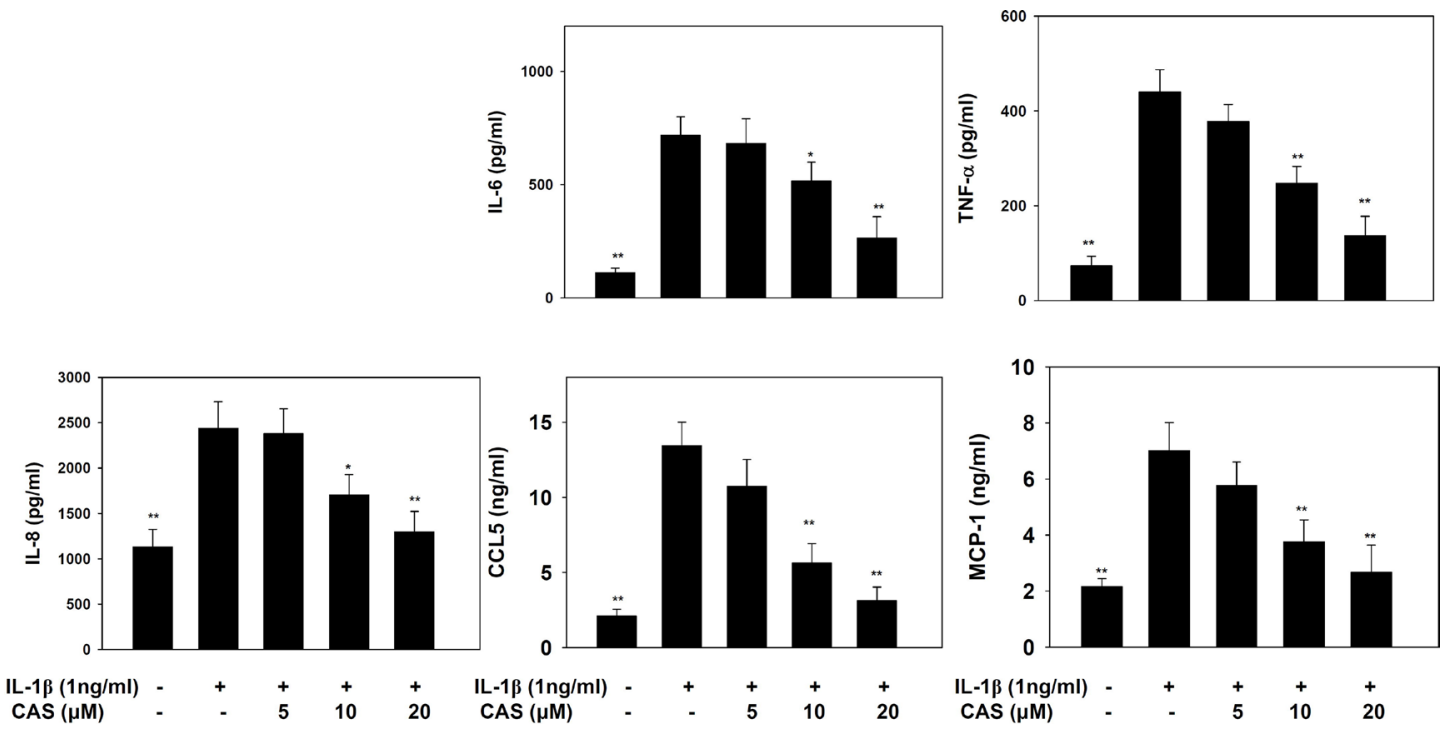

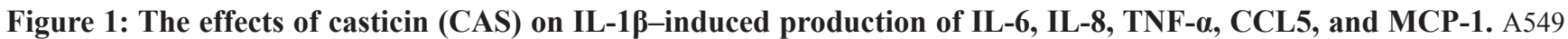
cells $\left(10^{6}\right.$ cells/well $)$ were pretreated with CAS for $1 \mathrm{~h}$ and then stimulated with IL-1 $\beta(1 \mathrm{ng} / \mathrm{ml})$ for $24 \mathrm{~h}$. The presented data are mean \pm SEM; ${ }^{*} p<0.05,{ }^{* *} p<0.01$, compared with the IL-1 $\beta$-treated group. 
MAPK, and Akt/PI3K pathways in IL-1 $\beta$-induced A549 cells. The results showed that casticin significantly suppressed phosphorylation of JNK, p38, and ERK1/2 (Figure 6A, 6B). In addition, casticin decreased Akt and PI3K phosphorylation compared with IL-1 $\beta$-activated A549 cells (Figure 6C, 6D). Furthermore, it significantly suppressed I $\mathrm{B}-\alpha$ phosphorylation, increased I $\alpha$ B- $\alpha$ degradation, and reduced p65 translocation into the nucleus compared with IL-1 $\beta$-induced A549 cells (Figure $7 \mathrm{~A}-7 \mathrm{C})$. The NF- $\mathrm{B}$ promoter assay results showed that casticin significantly reduced luciferase activity compared with IL-1 $\beta$-stimulated A549 cells (Figure 7D). When PI3K, AKT, MAPK, and NF- $\kappa \mathrm{B}$ inhibitors were used to evaluate the inhibitory effect of casticin on ICAM-1 expression with real-time PCR, we found that it could also enhance ERK, p38, PI3K, and NF- $\mathrm{KB}$ inhibitors to suppress ICAM-1 gene expression (Figure 8).

\section{DISCUSSION}

The fruit of $V$. rotundifolia is a medical herb commonly used to treat inflammation, colds, bronchitis, and headaches in traditional medicine [32]. Casticin is a flavonoid isolated from $V$. rotundifolia [29]. Recent studies have found that casticin has potential anticancer effects by inducing apoptosis of cancer cells, including human lung cancer, hepatocellular carcinoma, gastric cancer, glioma, and cervical cancer cells [32-36]. Casticin also can suppress ICAM-1 expression, decrease eosinophil migration into lung epithelial cells, and attenuate the acute lung inflammatory response in cigarette smoke-induced lung disease in mice $[28,37]$. Previously, we found that casticin has an anti-inflammatory effect of suppressing proinflammatory cytokines by blocking the MAPK, $\mathrm{NF}-\kappa \mathrm{B}$, and Akt signaling pathways in LPS-stimulated macrophages [30]. In the present study, casticin decreased ICAM-1 expression and suppressed the ability of monocyte THP-1 cells to adhere to IL- $1 \beta$-stimulated A549 cells. Casticin reduced levels of COX-2 and $\mathrm{PGE}_{2}$ and decreased proinflammatory cytokine and chemokine protein and gene expression. Casticin also significantly reduced inflammatory process-associated signaling pathways, including phosphorylation of Akt-PI3K and MAPKs and NF- $\kappa$ B p 65 translocation into the nucleus. Thus, we suggest that casticin may ameliorate the inflammatory effect in IL-1 $\beta$-stimulated lung epithelial cells.
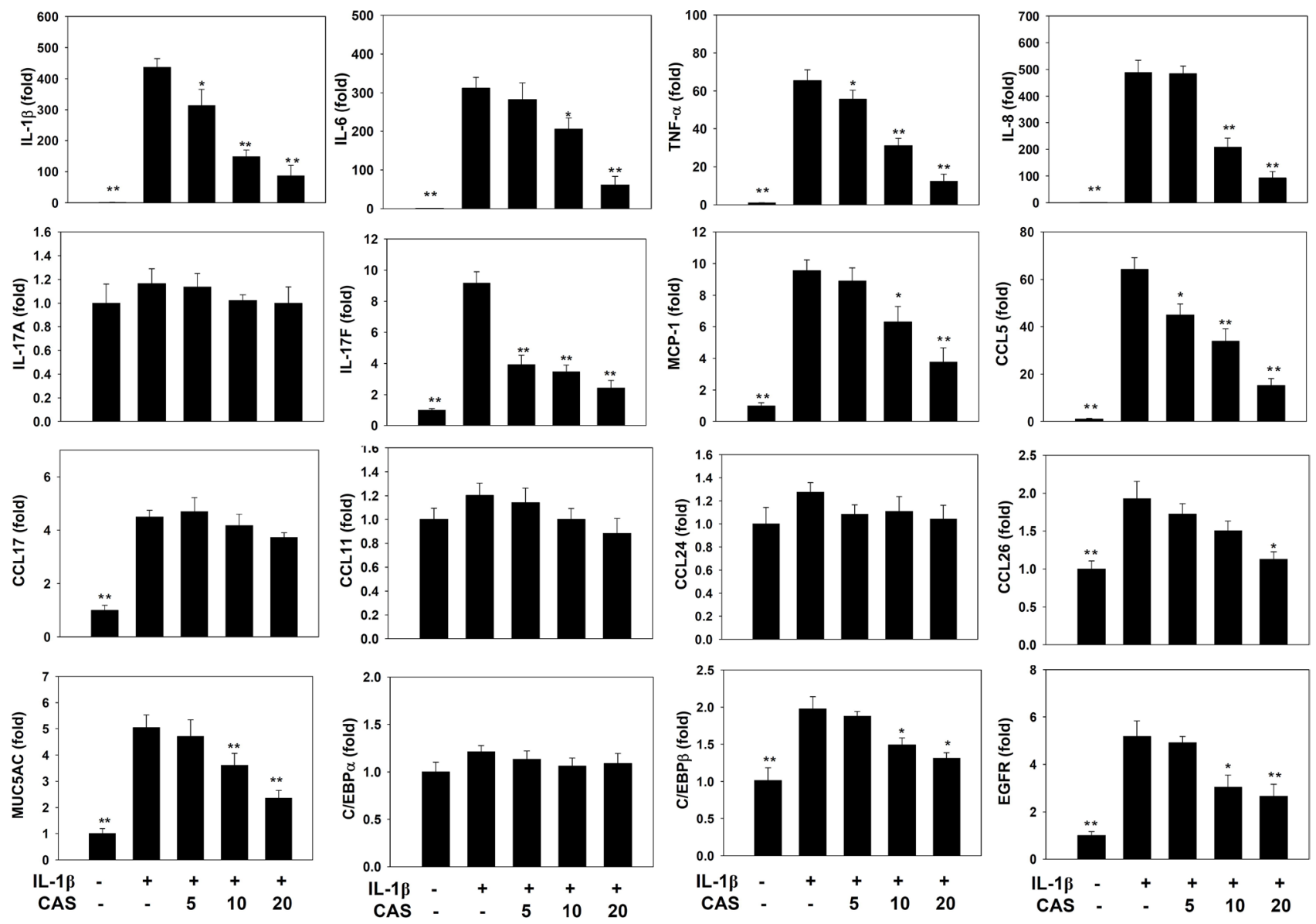

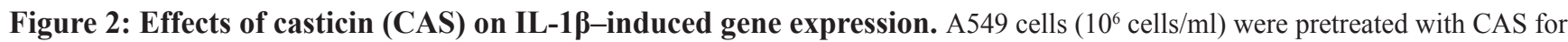
$1 \mathrm{~h}$ and then stimulated with IL-1 $\beta(1 \mathrm{ng} / \mathrm{ml})$ for $4 \mathrm{~h}$ to assay gene expression levels, determined using real-time RT-PCR. The presented data are mean $\pm \mathrm{SEM} ;{ }^{*} p<0.05,{ }^{* *} p<0.01$, compared with the IL-1 $\beta$-treated group. 
IL-1 $\beta$, is belonged to inducible proinflammatory cytokine, did not generally secrete in healthy tissue $[7,31]$. In the development of chronic or acute inflammatory diseases, the tissue expressed high amount of IL-1 $\beta$ to cause cell and tissue damage $[1,15]$. When Gram-negative bacteria infect the lungs, they release LPS, which stimulates macrophage activation and excessive secretion of inflammatory cytokines IL- $1 \beta$, TNF- $\alpha$, and IL-6 [20, 38]. Those cytokines irritate and destroy lung epithelial cells, leading to airway inflammation related to bacteria pneumonia or lung injury $[10,20]$. Recent studies have found that IL-1 $\beta$ is the major cytokine inducing lung inflammation in acute respiratory distress syndrome, which involves a decrease in blood oxygen that is sufficient to cause hypoxic damage [39]. Idiopathic pulmonary fibrosis is a progressive lung disease involving IL-1 $\beta$-stimulated lung epithelial cells in which epithelial repair processes, lung inflammation, and fibroproliferation are triggered [40]. IL-1RA can bind the IL-1 receptor to block the activity of the IL- $1 \beta$ signaling pathway [41] and ameliorate eosinophil infiltration, airway hyperresponsiveness, Th2 cytokine levels in bronchoalveolar lavage fluid, and airway remodeling in asthmatic mice [42]. Additionally, in idiopathic pulmonary fibrosis, the lung expresses high levels of IL-1 $\beta$, IL-17A, and IL-23. Treatment with IL-1RA suppresses IL-23 and IL-17A production and attenuates the symptoms of idiopathic pulmonary fibrosis [40]. In this study, we showed that casticin more significantly suppresses ICAM1 and MUC5AC gene expression when IL-1 $\beta$-stimulated A549 cells are treated with IL-1RA. Hence, casticin exerts an inflammatory effect by blocking the IL- $1 \beta$ pathway in lung epithelial cells. Furthermore, previous study found that H460 cells treated with epidermal growth factor, and H460 cells could significantly increase the levels of IL-6 and IL-6 receptor [43]. Hence, suppressed interleukin-6 receptor could reduce the proliferation of H460 cells for lung cancer therapeutics [43]. However, we found that IL-1 $\beta$-stimulated H460 did not significantly increase IL-6 and IL- 8 productions. We thought that $\mathrm{H} 460$ did not have
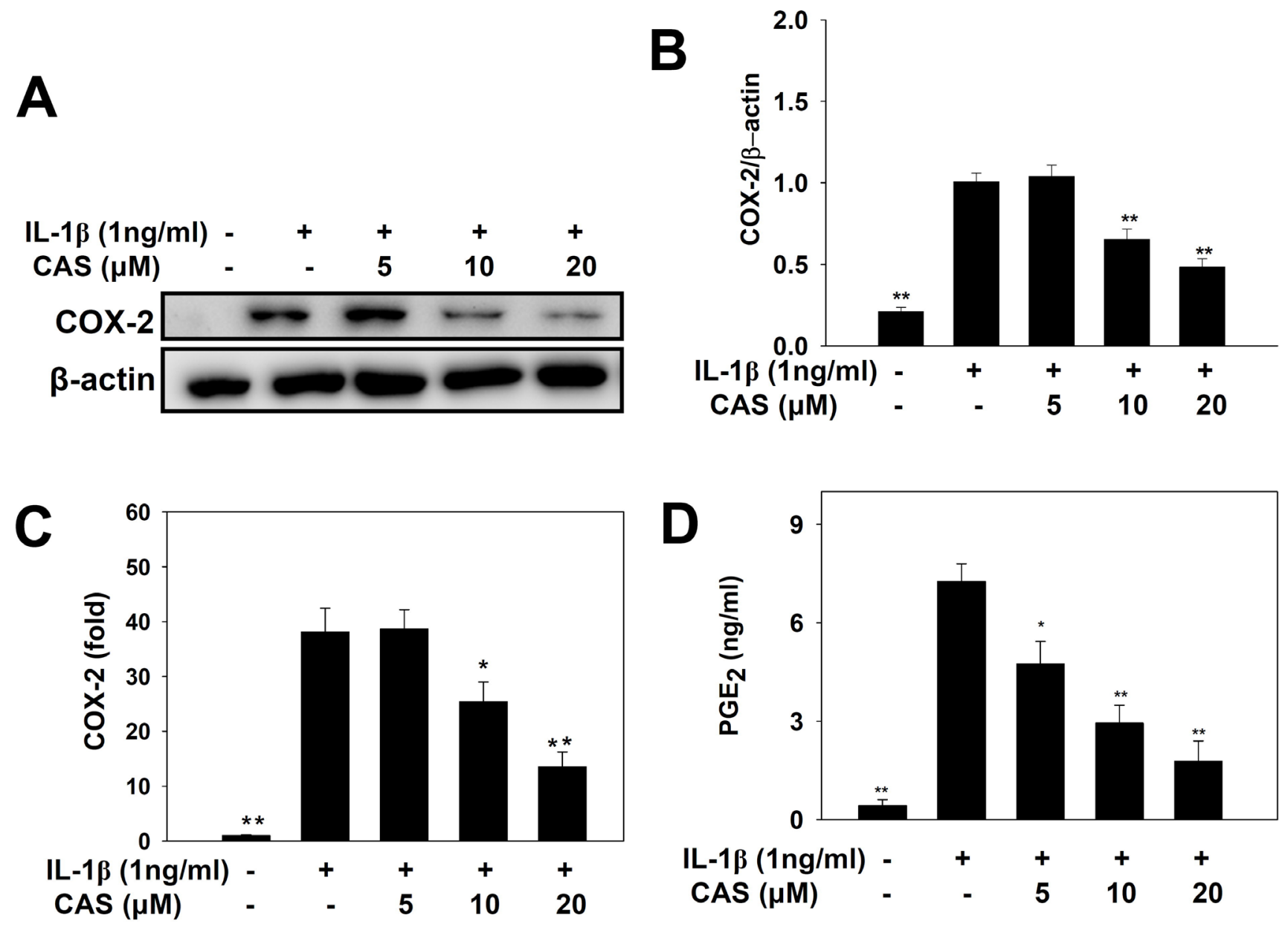

Figure 3: Effects of casticin (CAS) on IL-1 $\boldsymbol{\beta}$-induced production of COX-2 and PGE $\mathbf{2}_{\mathbf{2}}$ A549 cells $\left(10^{6} \mathrm{cells} / \mathrm{ml}\right)$ were pretreated with CAS for $1 \mathrm{~h}$ and then stimulated with IL-1 $(1 \mathrm{ng} / \mathrm{ml})$ for $24 \mathrm{~h}$. COX-2 proteins were detected using $\beta$-actin as an internal control (A), and COX-2 protein expressions were measured relative to the expression of $\beta$-actin (internal control) (B). COX-2 gene expression was measured by real-time PCR $(\mathbf{C})$, and levels of PGE $_{2}$ were evaluated by ELISA (D). Data are presented as mean \pm SEM; ${ }^{*} p<0.05,{ }^{* *} p<0.01$, compared with the IL-1 $\beta$-treated group. 
IL-1 receptors to induce the IL- $1 \beta$ signaling pathway for increasing IL-8 and IL-6 expression.

ICAM-1 is a cell adhesion molecule, and inflammatory lung epithelial cells highly express ICAM-1, leading to greater adherence of neutrophils or monocytes that infiltrate the lung tissue [44]. These neutrophils or monocytes release excessive proinflammatory cytokines that aggravate damage and inflammation [41, 45]. In the current study, we confirm that casticin reduces ICAM-1 gene expression and protein production and suppresses the promoter activity of ICAM-1 in inflammatory A549 cells. However, casticin also did not significantly modulate VCAM-1 gene expression in IL-1 $\beta$-stimulated A549 human lung epithelial cells (data not shown).We also found that casticin reduced THP-1 adhesion to A549 cells and blocked entry of more inflammatory cells. Therefore, we thought that casticin mainly inhibited
ICAM-1 expression to block inflammatory cells into the lung tissus.

Casticin could inhibite NF- $\kappa \mathrm{B}, \mathrm{PI} 3 \mathrm{~K} / \mathrm{Akt}$, and MAPK activity. PI3K/Akt signaling can induce NF$\kappa \mathrm{B}$ activity and translocation into the nucleus. IL$1 \beta$-stimulated A549 cells also use MAPK signaling to regulate NF-kB activation for ICAM-1 expression $[44,46]$. IL-1 $\beta$-stimulated A549 cells treated with NF- $\kappa B$, $\mathrm{PI} 3 \mathrm{~K} / \mathrm{Akt}$, and MAPK inhibitors along with casticin and found more significantly decreased ICAM-1 expression compared with IL-1 $\beta$-stimulated A549 cells. JNK and Akt inhibitor co-cultured with casticin did not significantly suppress ICAM-1 expression, however.

Epithelial cells of airways and lung tissue secrete mucus in response to toxic particles and microbes to protect against lung damage [1,47]. Inhaled smoke or nicotine is associated with many lung diseases, including

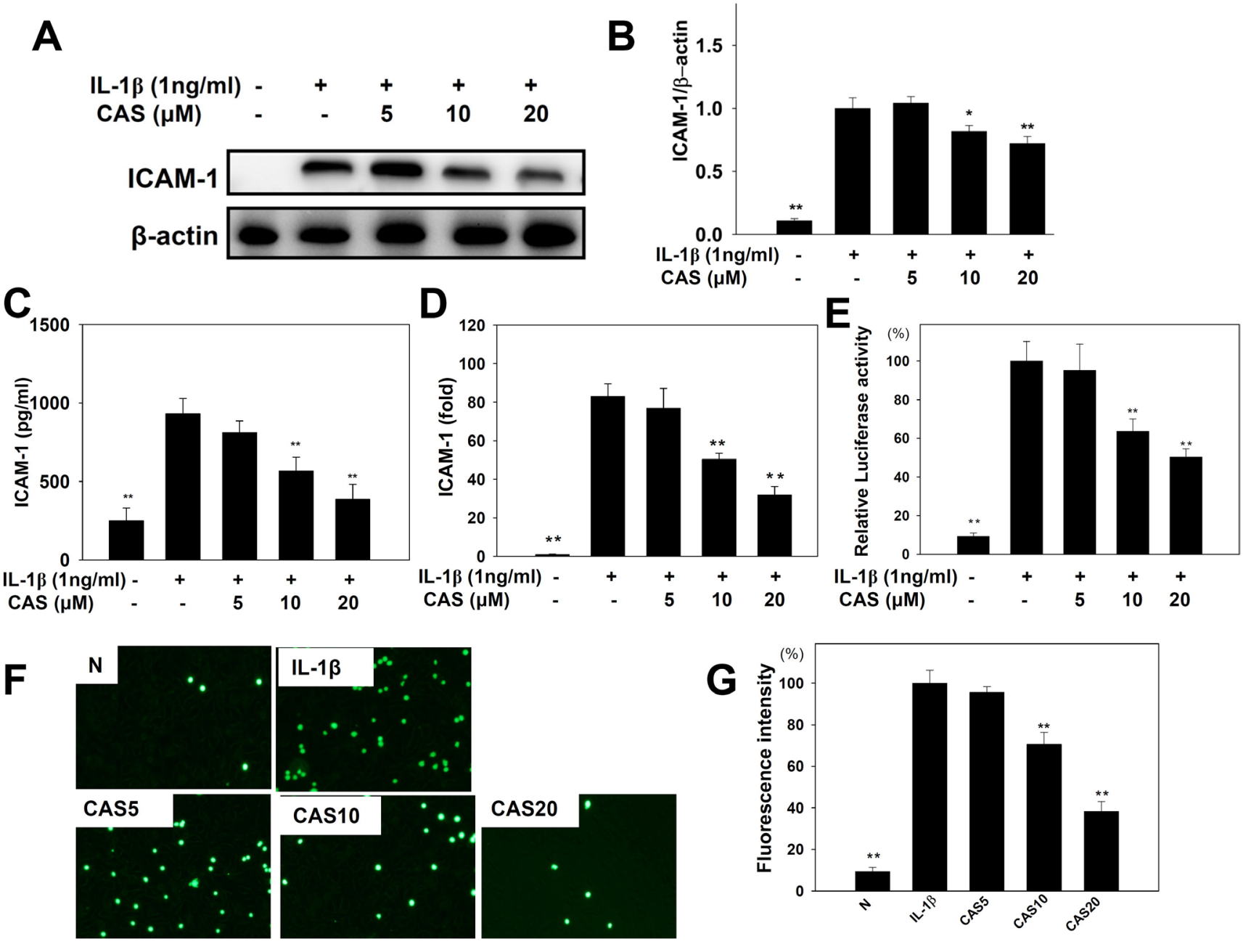

Figure 4: Effects of casticin (CAS) on IL-1ß-induced production of ICAM-1. A549 cells (10 cells $/ \mathrm{ml})$ were pretreated with CAS for $1 \mathrm{~h}$ and then stimulated with IL-1 $\beta(1 \mathrm{ng} / \mathrm{ml})$ for $24 \mathrm{~h}$ to assay ICAM-1 protein expression by western blot (A), and ICAM-1 protein expressions were measured relative to the expression of $\beta$-actin (internal control) (B). ICAM-1 of the culture medium by ELISA (C). ICAM-1 gene expression levels, determined using real-time RT-PCR (D), and promoter assay were used to evaluate ICAM-1 promoter activity (E). THP-1 cells were labeled with calcein AM and co-cultured with A549 cells, followed by observation using fluorescence microscopy (F). Fluorescence intensity of THP-1 cell adhesion to A549 cells $(\mathbf{G})$. The presented data are mean \pm SEM; ${ }^{*} p<0.05$, ${ }^{* *} p<0.01$, compared with the IL- $1 \beta$-treated group. 
emphysema, chronic bronchitis, and COPD, and inhaled allergens may cause asthma [3, 48]. Emphysema is a chronic pulmonary disease that causes difficulty breathing by alveolar overinflation [49]. In chronic bronchitis, tobacco smoke can lead to inflammation of airways for reduced air flow and caused coughing [1]. These lung diseases involve relatively more mucin secretion in the epithelial layers of airways. Cilia are the principal cells on the surface epithelium of intrapulmonary airways for excluding inhaled microbes and dust $[50,51]$. Epithelial cells also release more antimicrobial molecules, including IgA and lysozyme, against microbial infections [1]. However, when inflammatory lung epithelial cells secrete excessive mucus, the airway can be obstructed, causing difficulty breathing and suffocation [52]. Casticin has an anti-inflammatory effect and significantly suppressed MUC5AC expression in A549 cells in the current work.

The COX-2 inhibitor meloxicam suppresses arachidonic acid conversion into $\mathrm{PGE}_{2}$ [53]. We
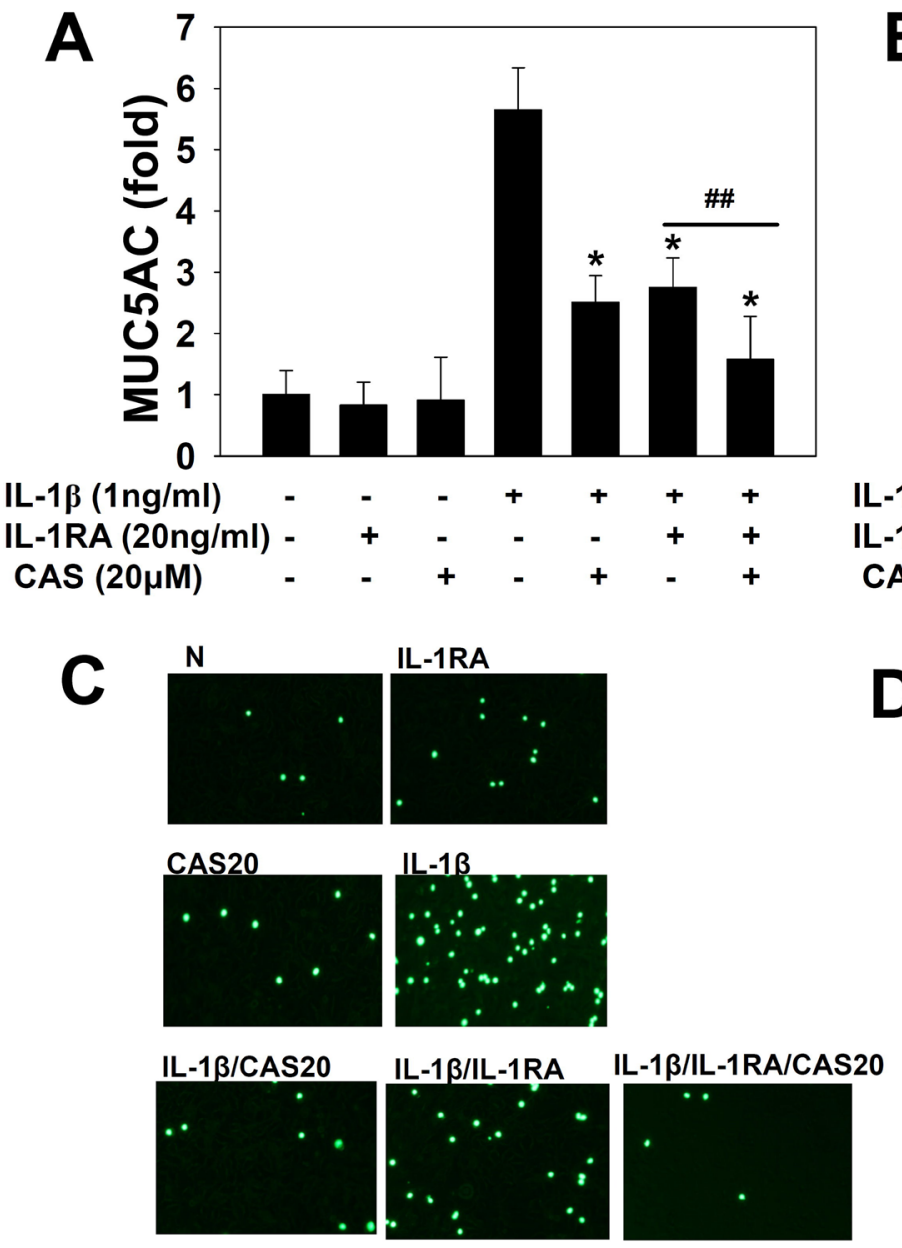

previously found that casticin has an anti-inflammatory effect by decreasing COX-2 and $\mathrm{PGE}_{2}$ production in LPSstimulated macrophages [30]. In the current work, casticin also significantly reduced $\mathrm{COX}-2$ and $\mathrm{PGE}_{2}$ production in IL-1 $\beta$-activated A549 cells.

Neutrophils are essential for removing bacterial infections in acute inflammatory lung disease [31]. Lung epithelial cells of patients release IL- 8 to attract more neutrophils against microbe infection [54], and inflammatory epithelial cells secrete more IL-1 $\beta$, IL-6, TNF- $\alpha$, CCL5, MCP-1, and IL-17 to activate the inflammatory warning signal [51]. However, those inflammatory responses of the airways also can cause lung injury and physical discomfort. Casticin significantly reduces inflammatory cytokine and chemokine production in inhibiting the inflammatory response of lung epithelial cells. A previous study found that A549 cells stimulated with TNF- $\alpha /$ IL-4/IL-1 $\beta$ release eotaxin and that casticin suppresses eotaxin production [28]. Interestingly, we

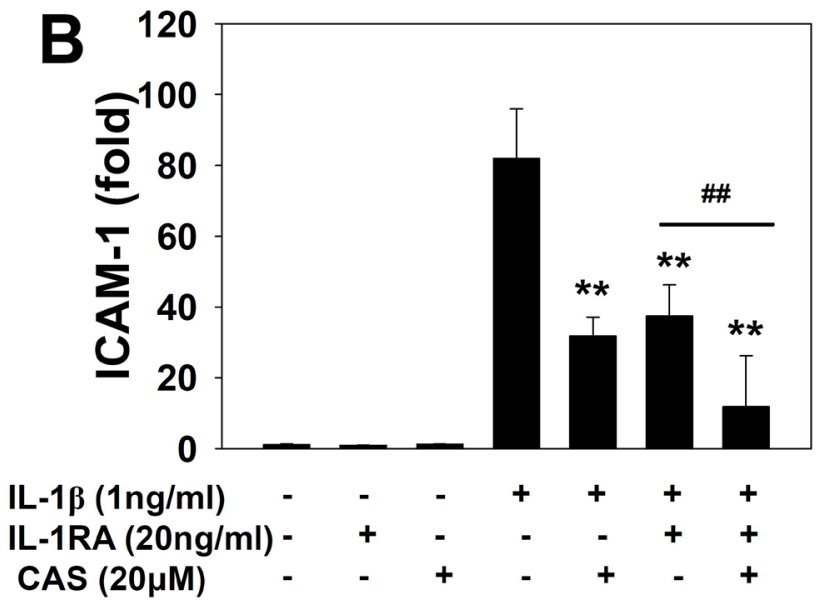

D

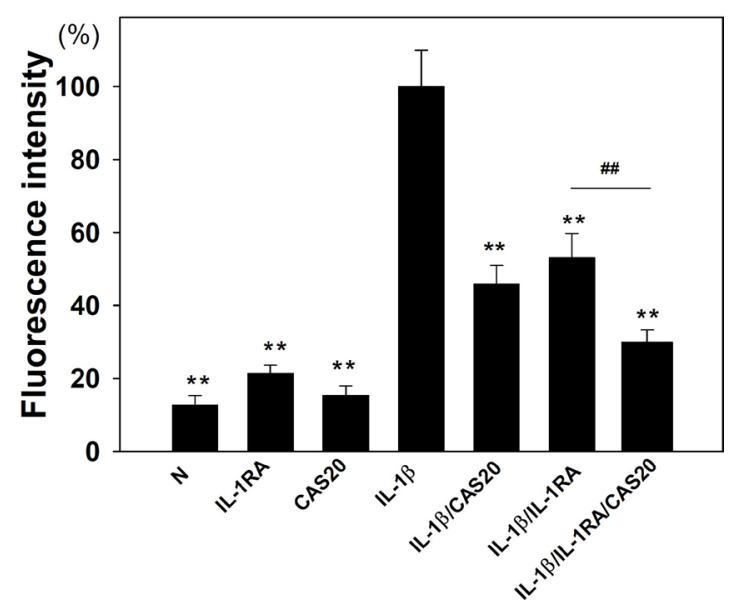

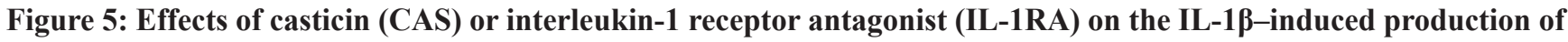
ICAM-1 and MUC5AC. A549 cells $\left(10^{6} \mathrm{cells} / \mathrm{ml}\right)$ were pretreated with casticin (CAS) or $(20 \mathrm{ng} / \mathrm{ml}) \mathrm{IL}-1 \mathrm{RA}$ for $1 \mathrm{~h}$ and then stimulated with IL-1 $\beta(1 \mathrm{ng} / \mathrm{ml})$ for $4 \mathrm{~h}$ to assay MUC5AC (A) and ICAM-1 (B) gene expression, determined using real-time RT-PCR. THP-1 cells were labeled with calcein AM and co-cultured with A549 cells, followed by observation using fluorescence microscopy (C). Fluorescence intensity of THP-1 cell adhesion to A549 cells (D). The presented data are mean \pm SEM; ${ }^{*} p<0.05,{ }^{* *} p<0.01$, compared with the IL-1 $\beta$ treated group. ${ }^{*} p<0.05,{ }^{*} p<0.01$, compared with the IL-1 $\beta /$ IL-1RA group. 
found that casticin did not decrease eotaxin (e.g., CCL11 and CCL24 expression) in IL-1 $\beta$-stimulated A549 cells. Our previous study found that human bronchial epithelial (BEAS-2B) cells induce eotaxin expression by stimulation with TNF- $\alpha / \mathrm{IL}-4$ [45]. Thus, we speculate that IL-1 $\beta$-stimulated A549 cells in the current work did not significantly release more eotaxin to attract eosinophil migration. CCL17, is a thymus and activationregulated chemokine, associated with chronic pulmonary inflammation in asthma [55]. A previous study found that CCL17 could selectively attract Th2 cells activation in asthmatic mice [56]. Casticin did not modulate CCL17 gene expression in IL-1 $\beta$-stimulated A549 cells. We speculated that casticin did not suppress CCL17 production for blocked more Th2 cells infiltration into the lung tissue. Furthermore, EGFR could enhance inflammatory responses in A549 cells [57]. C/EBP transcription factors also modulate inflammatory gene expression in lung diseases [58], and here we found that casticin represses C/EBP $\beta$ and EGFR inflammatory gene expression in A549 cells.

Airways affected by airborne microbes, smoke, or air pollution activate lung epithelial cells and macrophages to secrete a number of proinflammatory cytokines and mediators that contribute to the pathophysiology of pneumonia $[10,59]$. Casticin decreased proinflammatory cytokine, chemokines, ICAM-1, and MUC5AC expression by blocking activation of the NF- $\mathrm{B}$, PI3K-Akt, and MAPK signaling pathways in IL- $\beta$-activated human lung epithelial cells (Figure 9). Casticin also suppressed leukocyte adherence to lung epithelial cells by reducing ICAM-1 expression via inhibition of the IL- $1 \beta$ pathway. This compound holds potential as a natural antiinflammatory drug that could ameliorate inflammatory lung disease.

\section{MATERIALS AND METHODS}

\section{Materials}

Casticin ( $\geq 98 \%$ purity by HPLC) was purchased from Sigma-Aldrich (Sigma, St. Louis, MO, USA) and dissolved in DMSO. The concentration of the stock solution was $100 \mathrm{mM}$. DMSO was $\leq 0.1 \%$ in culture medium, as previously described [30].

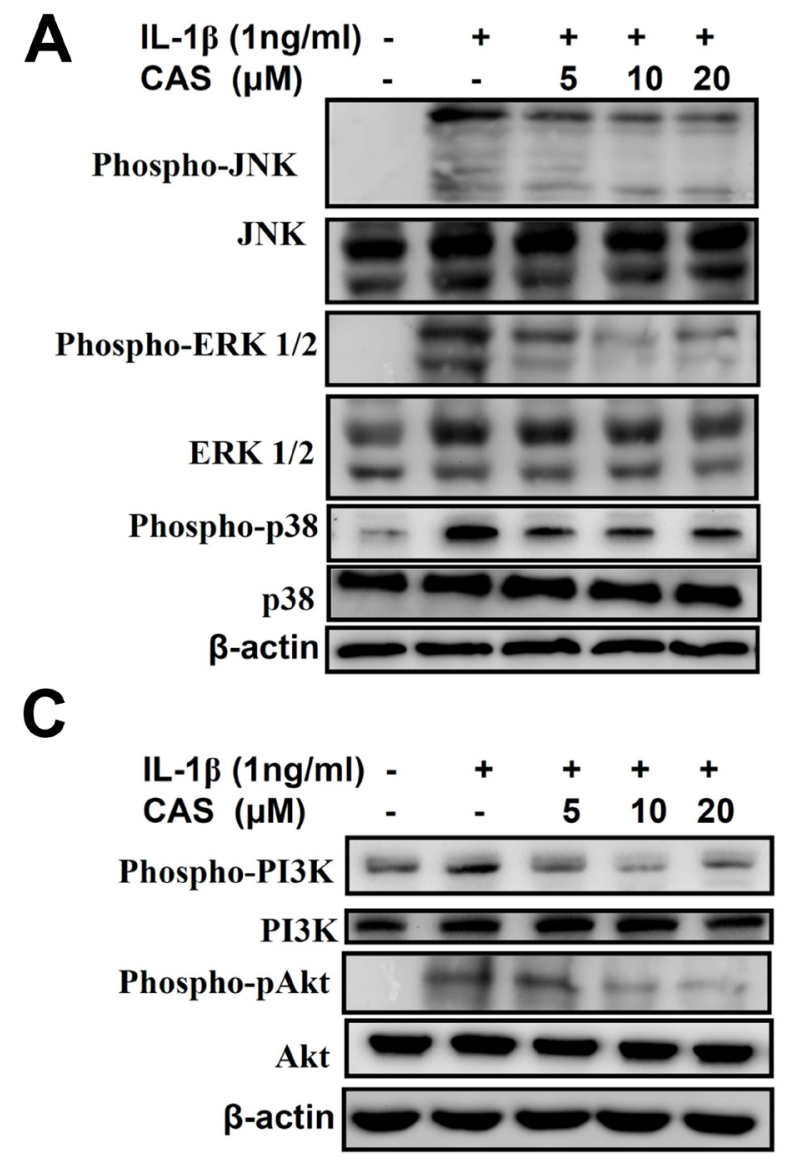

B
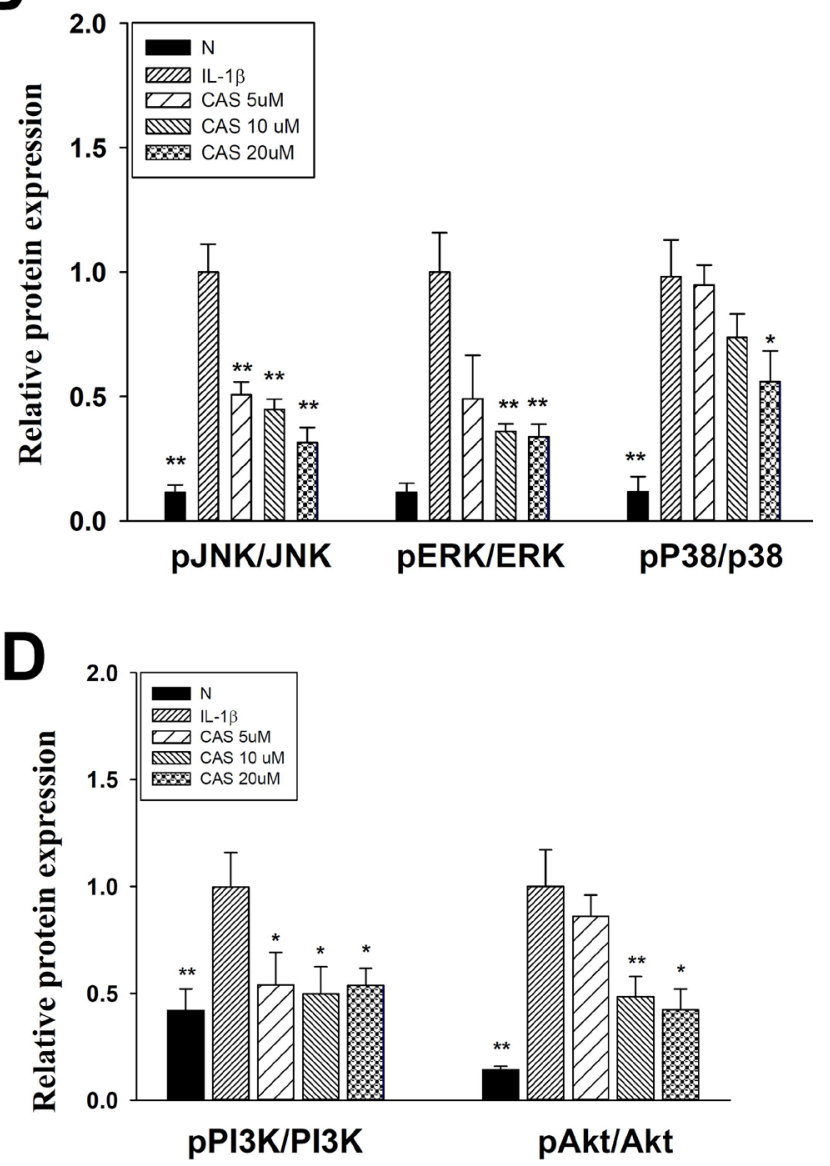

Figure 6: Effect of casticin (CAS) on IL-1 $\beta$-induced activation of PI3K-Akt, and MAPK signaling in A549 cells. A549 cells were pretreated with CAS for $1 \mathrm{~h}$ and then incubated with IL-1 $\beta(1 \mathrm{ng} / \mathrm{ml})$ for $30 \mathrm{~min}$. Phospho-specific proteins were detected using western blot, and total MAPK (A, B) and PI3K/Akt (C, D) levels were used as internal controls. The presented data are mean \pm SEM; ${ }^{*} p<0.05,{ }^{* *} p<0.01$, compared with the IL-1 $\beta$-treated group. 


\section{Cell line and culture medium}

Human lung epithelial A549 cells and H460 cells were obtained from the Bioresource Collection and Research Center (BCRC, Taiwan). Cells were routinely cultured in Dulbecco's modified Eagle's medium (Invitrogen-Gibco ${ }^{\mathrm{TM}}$, Paisley, Scotland) supplemented with $10 \%$ fetal bovine serum, $100 \mathrm{U} / \mathrm{ml}$ penicillin, and $100 \mu \mathrm{g} / \mathrm{ml}$ streptomycin. Cells were incubated in $5 \% \mathrm{CO}_{2}$ humidified air at $37^{\circ} \mathrm{C}$ and subcultured twice each week.

\section{Cell viability assay}

Cell viability was measured using the MTT assay, as previously described [60]. In brief, A549 and H460 cells were seeded in 96-well plates and treated with various concentrations of casticin in each well, and the plates were incubated at $37^{\circ} \mathrm{C}$ for $24 \mathrm{~h}$. An MTT working solution $(5 \mathrm{mg} / \mathrm{ml})$ was added to the plates for $4 \mathrm{~h}$ at $37^{\circ} \mathrm{C}$, and then formazan crystals were dissolved using isopropanol. Finally, the absorbance of each well at $570 \mathrm{~nm}$ was measured with a microplate reader (Multiskan
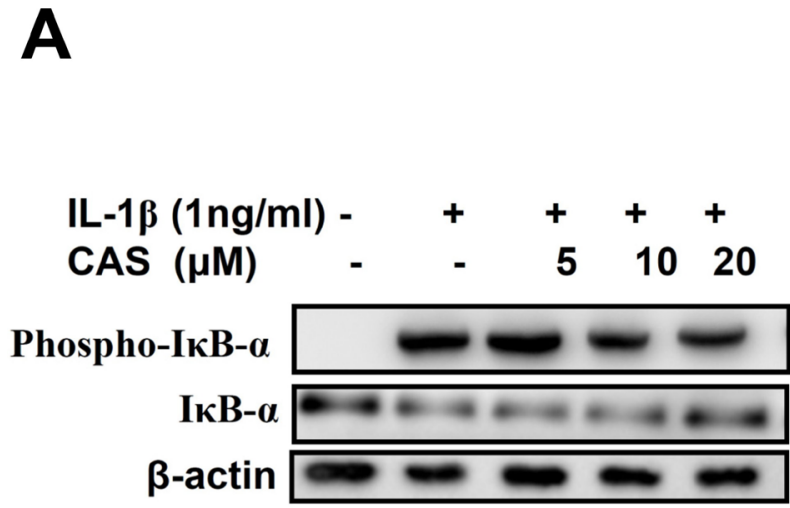

C

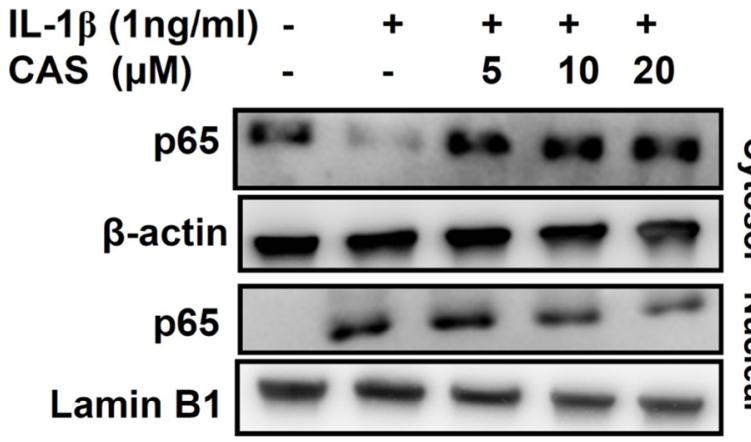

FC, Thermo, Waltham, MA, USA). Three independent experiments were carried out for each of the different treatments.

\section{RNA isolation and real-time PCR for gene expression}

Total RNA for detection of A549-related cytokines, chemokines, and ICAM-1 was extracted after stimulation and treatment with casticin. cDNA was synthesized using a cDNA synthesis kit (Life Technologies), and gene expression was measured by incorporation of fluorescent SYBR Green using a spectrofluorometric thermal cycler (iCycler; Bio-Rad Laboratories, Hercules, CA, USA). Specific primers were designed as shown in Table 1. PI3K inhibitor (AS604850) and AKT inhibitor (Akt1/2 kinase inhibitor) (Sigma), NF-kB inhibitor (BAY117085), and MAPK inhibitors (JNK inhibitor SP600125, ERK inhibitor PD98059, and p38 inhibitor SB203580) (Enzo Life Sciences, Inc., Farmingdale, NY, USA) were cultured with casticin for detection of ICAM-1 gene expression.
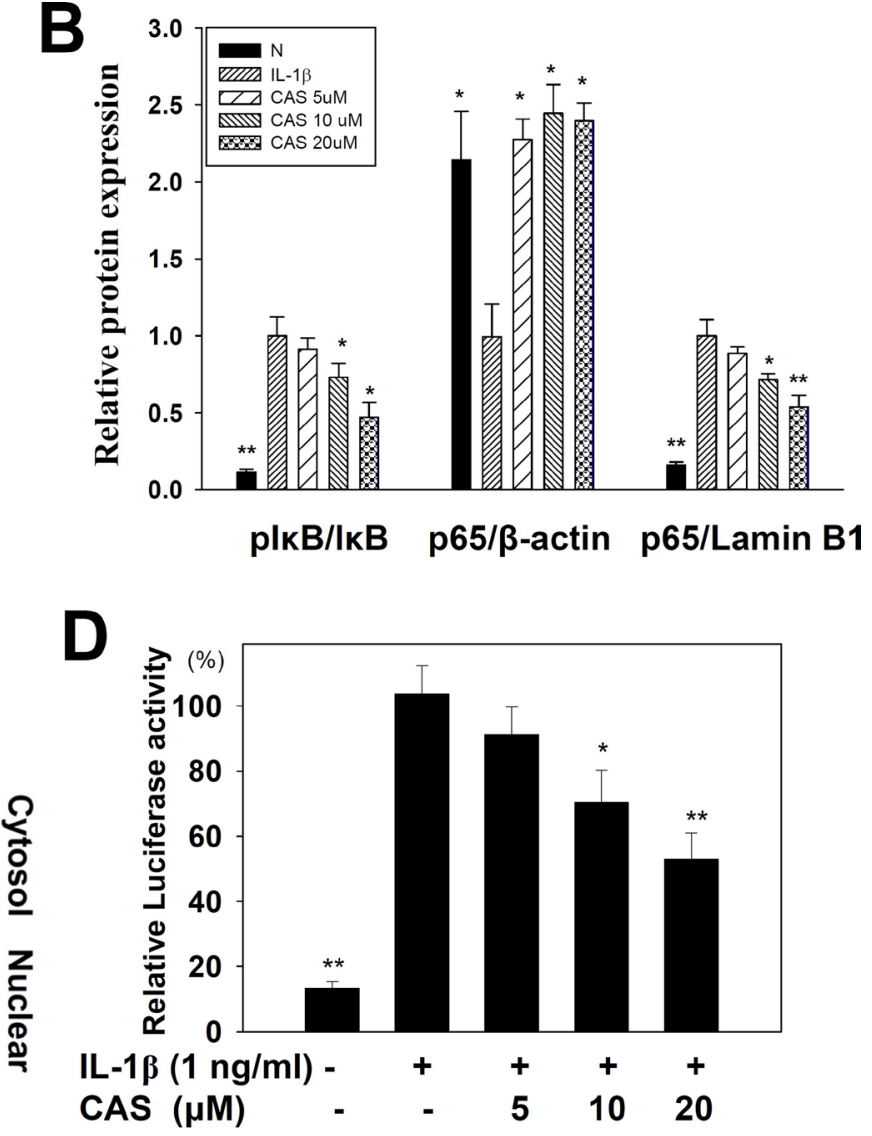

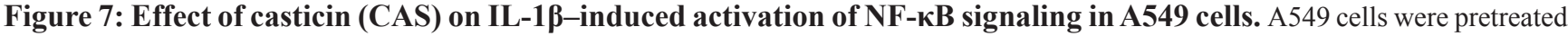
with CAS for $1 \mathrm{~h}$ and then incubated with IL-1 $(1 \mathrm{ng} / \mathrm{ml})$ for $30 \mathrm{~min}$. Phospho-specific proteins were detected using western blot, and total IкB- $\alpha(\mathbf{A}, \mathbf{B})$ levels were used as internal controls. For the nuclear translocation of NF-kB, cells were pretreated with $\mathrm{CAS}$ for $1 \mathrm{~h}$ and then incubated with IL-1 $\beta(1 \mathrm{ng} / \mathrm{ml})$ for $1 \mathrm{~h}(\mathrm{~B}, \mathbf{C})$. The internal controls were Lamin B1 in the nucleus and $\beta$-actin in the cytosol. A promoter assay was used to evaluate NF-kB promoter activity (D). The presented data are mean $\pm \mathrm{SEM} ;{ }^{*} p<0.05,{ }^{* *} p<0.01$, compared with the IL-1 $\beta$-treated group. 


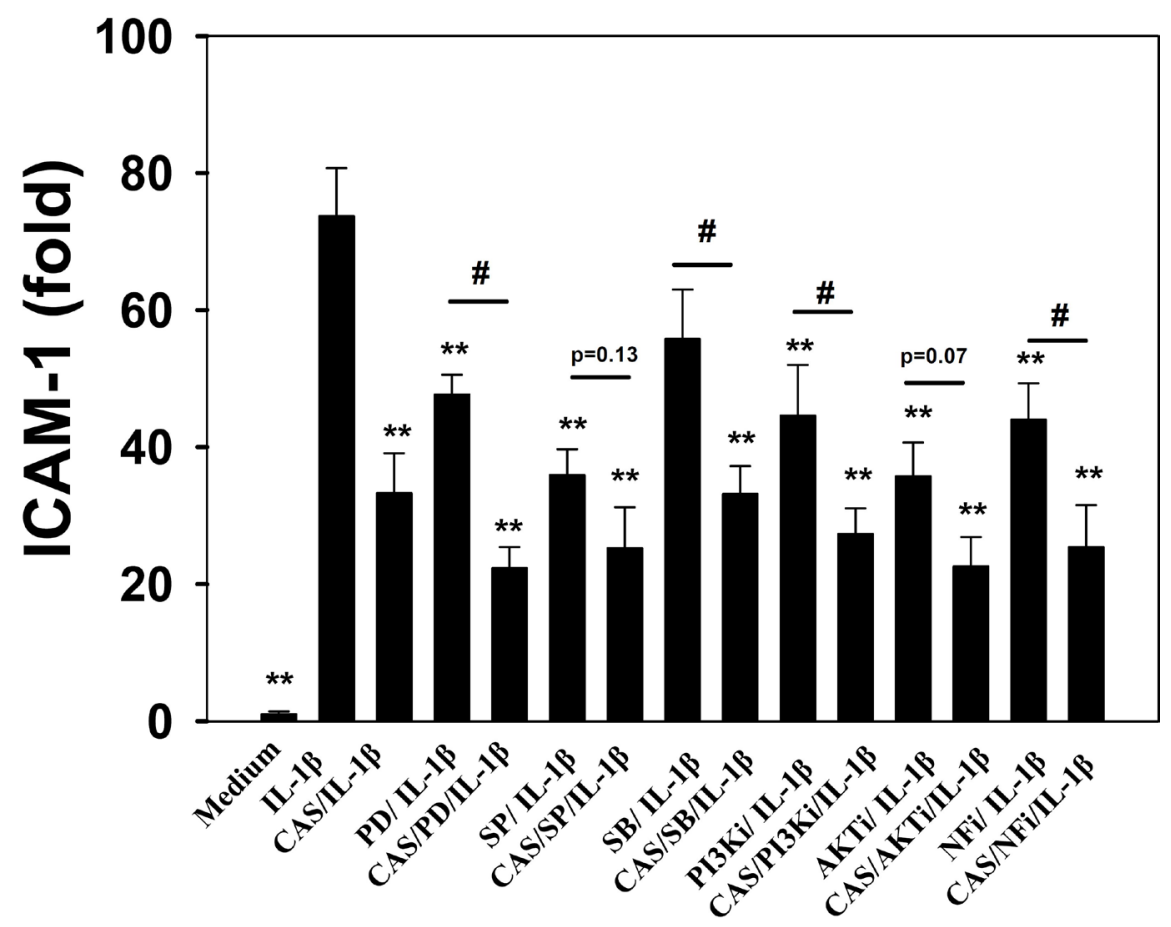

Figure 8: Inhibitory effects of MAPK, PI3K, Akt, and NF-кB inhibitors or casticin (CAS) on IL-1ß-induced ICAM-1 protein expression in A549 cells. A549 cells were pretreated with ERK1/2 inhibitors (PD: $10 \mu$ M PD98059), p38 inhibitors (SB: 10 $\mu \mathrm{M}$ SB203580), JNK inhibitors (SP: $10 \mu \mathrm{M}$ SP600165), PI3K inhibitor (PI3Ki: $10 \mu \mathrm{M}$ AS604850), AKT inhibitor (AKTi: $10 \mu \mathrm{M}$ Akt1/2 kinase inhibitor), and NF- $\kappa$ B inhibitor (NFi: $10 \mu \mathrm{M}$ BAY11-7085) with or without $20 \mu \mathrm{M}$ CAS for $1 \mathrm{~h}$, followed by IL-1 $\beta$ stimulation for 4 h. ICAM-1 gene expression was detected by real-time PCR. The presented data are mean \pm SEM; ${ }^{*} p<0.05,{ }^{* *} p<0.01$, compared with the IL-1 $\beta$-treated group. ${ }^{*} p<0.05,{ }^{*} p<0.01$, compared with the inhibitor / IL-1 $\beta$ group.

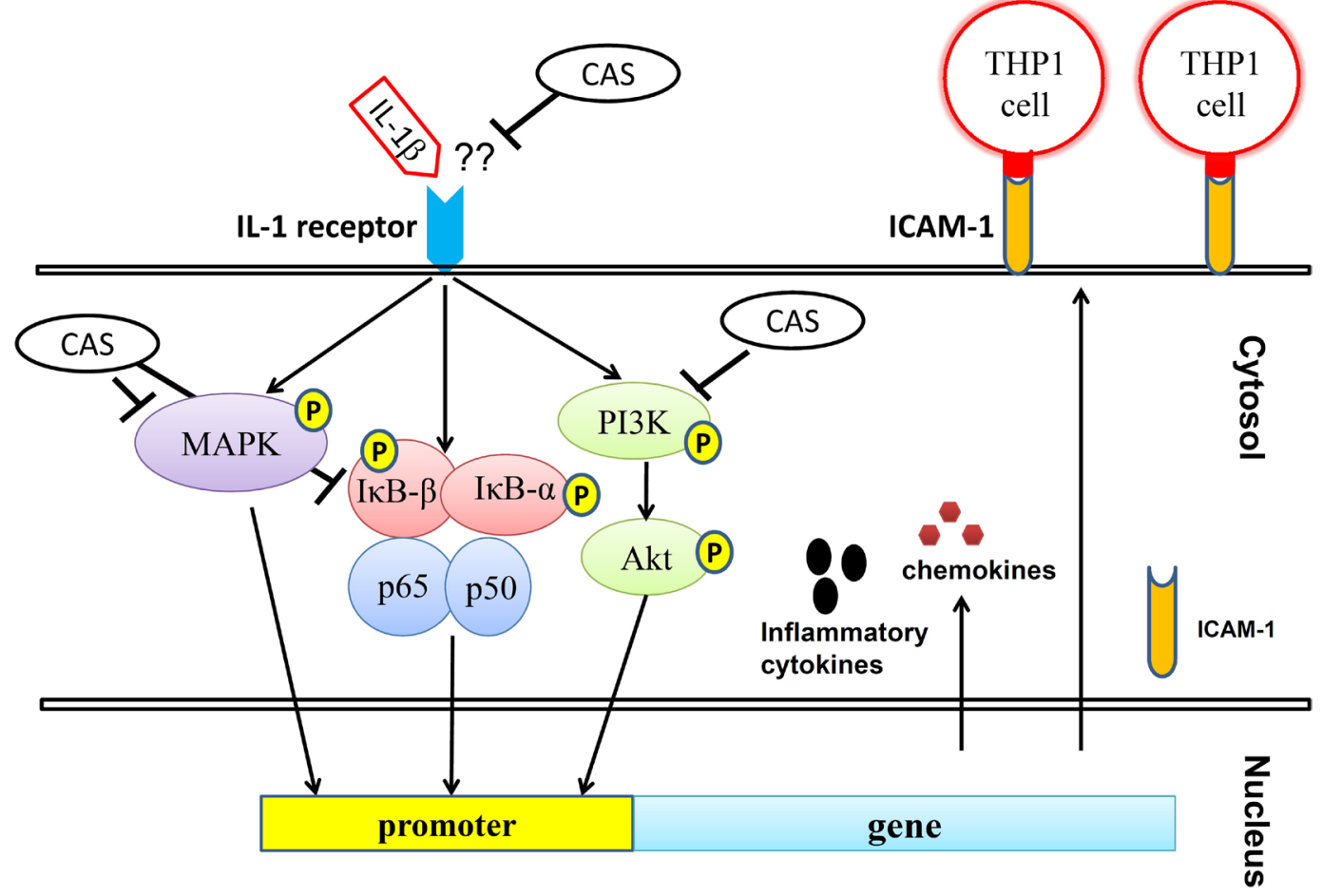

Figure 9: Model explaining the mechanism for the anti-inflammatory effects of casticin (CAS) in IL-1 $\beta$-induced A549 cells. 
Table 1: Primers used in real-time PCR analyses of mRNA expression

\begin{tabular}{|c|c|c|}
\hline Gene & Primer Forward & Primer Reverse \\
\hline CCL5 & CGAAGGAACCGCCAAGTGT & AGGACTAGAGCAAGCAATGAC \\
\hline CCL11 & GGCTTCATGTAGTTCCAGAT & CCATTGTGTTCCTCAATAATCC \\
\hline CCL17 & GCCTTGAGAGGTCTTGAAGC & TCACTGTGGCTCTTCTTCGT \\
\hline CCL24 & AGGCAGTGAGAACCAAGT & GCGTCAATACCTATGTCCAA \\
\hline CCL26 & AGACCTGCTGCTTCCAATACA & GGGTACAGACTTTCTTGCCTCT \\
\hline $\mathrm{COX}-2$ & ACCAGCAGTTCCAGTATCAGA & CAGGAGGATGGAGTTGTTGTAG \\
\hline IL-1 $\beta$ & CACTACAGGCTCCGAGATGA & CGTTGCTTGGTTCTCCTTGT \\
\hline IL-4 & TCCGTGCTTGAAGAAGAACTC & GTGATGTGGACTTGGACTCATT \\
\hline IL-6 & AGGACCAAGACCATCCAATTCA & GCTTAGGCATAACGCACTAGG \\
\hline IL-8 & GCAGAGGGTTGTGGAGAAGT & TGGCATCTTCACTGATTCTTGG \\
\hline IL-13 & GCTCCAGCATTGAAGCAGTG & CGTGGCAGACAGGAGTGTT \\
\hline IL-17A & CACCTCACCTTGGAATCTC & GGATCTCTTGCTGGATGG \\
\hline IL-17F & ACACAGGCATACACAGGAAGA & CCAATATCGACAGCAGCAAGTA \\
\hline MCP-1 & TTCCACAACCACCTCAAGCA & TTAAGGCATCACAGTCCGAGTC \\
\hline TNF- $\alpha$ & GCACCACCATCAAGGACTC & AGGCAACCTGACCACTCTC \\
\hline ICAM-1 & AACAGAATGGTAGACAGCAT & TCCACCGAGTCCTCTTAG \\
\hline MUC5AC & GTGTCCACTGTGTCCTCCTC & GGCTCGGTCGGTCTTATTGT \\
\hline $\mathrm{C} / \mathrm{EBP} \alpha$ & GACTTGGTGCGTCTAAGATGAG & TAGGCATTGGAGCGGTGAG \\
\hline $\mathrm{C} / \mathrm{EBP} \beta$ & GTCCAAACCAACCGCACAT & CAGAGGGAGAAGCAGAGAGTT \\
\hline EGFR & GCCAAGGCACGAGTAACAAG & CCAAGGACCACCTCACAGTT \\
\hline$\beta$-actin & AAGACCTCTATGCCAACACAGT & AGCCAGAGCAGTAATCTCCTTC \\
\hline
\end{tabular}

\section{ELISAs for chemokines, cytokines, and PGE production}

A549 and H460 cells were pretreated with or without casticin in 24-well plates for $1 \mathrm{~h}$, then stimulated with IL-1 $\beta(1 \mathrm{ng} / \mathrm{ml})$ and cultured for $24 \mathrm{~h}$ to assay chemokine, cytokine, and $\mathrm{PGE}_{2}$ production using specific ELISA kits (R\&D Systems, Minneapolis, MN, USA). The absorbance of each well at $450 \mathrm{~nm}$ was measured with a microplate reader (Multiskan FC, Thermo, Waltham, MA, USA). Three independent experiments were carried out for each of the different treatments.

\section{Preparation of total and nuclear proteins}

A549 cells were seeded in 6-well plates and treated with casticin for $1 \mathrm{~h}$. Then, cells were stimulated with IL-1 $\beta(1 \mathrm{ng} / \mathrm{ml})$ for $30 \mathrm{~min}$ to evaluate protein phosphorylation or for $24 \mathrm{~h}$ to detect total protein expression. Proteins were extracted using protein lysis buffer containing protease and phosphatase inhibitors (Sigma). Additionally, nuclear proteins were isolated using the NE-PER ${ }^{\circledR}$ nuclear and cytoplasmic extraction reagent kits (Pierce, Rockford, IL, USA), and proteins were quantified with the BCA protein assay kit (Pierce).

\section{Western blotting analysis}

Proteins were separated on SDS polyacrylamide gels and transferred onto PVDF membranes (Millipore, Billerica, MA, USA). The membranes were incubated overnight at $4{ }^{\circ} \mathrm{C}$ with specific primary antibodies, including Akt, phosphorylated-Akt, COX-2, IкB- $\alpha$, phosphorylated-IкB- $\alpha$, p65, and Lamin B1 (Santa Cruz, CA, USA); ERK1/2, phosphorylated-ERK 1/2, p38, phosphorylated-p38, JNK, and phosphorylatedJNK (Millipore); PI3K and phosphorylated-PI3K (Cell Signaling Technology, Inc., MA, USA); and ICAM-1 and $\beta$-actin (Sigma). The membrane was washed and incubated with secondary antibodies for $1 \mathrm{~h}$. Finally, specific proteins were detected with Luminol/Enhancer Solution (Millipore) using the BioSpectrum 600 system (UVP, Upland, CA, USA).

\section{Transient transfection and luciferase activity assay}

NF- $\mathrm{KB}$ activity was evaluated using transfected pNFkB-Luc plasmid (Stratagene, CA, USA), as previously described [45]. Additionally, we constructed the pICAM1Luc plasmid, in which the region of the human ICAM-1 promoter $(1.2-\mathrm{kb})$ in a luciferase reporter vector pMuc- 
Luc was amplified from A549 cells using PCR, and the DNA sequence was confirmed by dideoxynucleotide sequencing. A549 cells were transfected with $1 \mu \mathrm{g}$ pNF $\kappa$ BLuc or pICAM1-Luc plasmid using Lipofectamine 2000 (Life Technologies, Carlsbad, CA, USA) for 24 $\mathrm{h}$. The cells were treated with casticin for $1 \mathrm{~h}$, and then IL-1 $\beta$ was added for $4 \mathrm{~h}$. Luciferase activity was measured using a luciferase reporter assay kit (GeneDireX, Brussels, Belgium) and determined with a Multi-Mode microplate reader (BioTek Synergy HT, Bedfordshire, United Kingdom).

\section{Cell-cell adhesion assay}

A549 cells were pretreated with casticin and incubated with IL-1 $\beta$ for $24 \mathrm{~h}$. Then, they were treated with calcein AM (Sigma) from human monocytic THP-1 cells, which were co-cultured with A549 cells for $1 \mathrm{~h}$. Cells were observed using fluorescence microscopy (Olympus, Tokyo, Japan).

\section{Statistical analysis}

All experimental data were analyzed by one-way analysis of variance and post hoc analyses with Dunnett's test. Data are presented as the mean \pm SEM of at least three independent experiments, and statistical significance was set at $p<0.05$.

\section{Abbreviations}

COX-2: cyclooxygenase 2; EGFR: epidermal growth factor receptor; ICAM-1: intercellular adhesion molecule 1; IL-1 $\beta$ : interleukin-1 $\beta$; MAPK: mitogen-activated protein kinase; MUC5AC: mucin 5AC; PI3K: phosphatidylinositol 3-kinase; NF- $\mathrm{B}$ : nuclear transcription factor kappa-B; $\mathrm{PGE}_{2:}$ prostaglandin E2; TNF- $\alpha$ : tumor necrosis factor $\alpha$.

\section{Author contributions}

Aesigned and performed the experiments: C.J.L. and W.C.H.; Analysis and interpretation of data: C.J.L; Drafting the manuscript: W.C.H.

\section{ACKNOWLEDGMENTS}

This study was supported in part by grants from the Chang Gung Memorial Hospital (CMRPF1D0101 and CMRPF1C0183) and and from the Chang Gung University of Science and Technology (EZRPF3F3F0241 and EZRPF3F3F0251).

\section{CONFLICTS OF INTEREST}

The authors declare that there are no conflicts of interest.

\section{REFERENCES}

1. Gohy ST, Hupin C, Pilette C, Ladjemi MZ. Chronic inflammatory airway diseases: the central role of the epithelium revisited. Clin Exp Allergy. 2016; 46:529-42.

2. Peters-Hall JR, Brown KJ, Pillai DK, Tomney A, Garvin LM, $\mathrm{Wu}$ X, Rose MC. Quantitative proteomics reveals an altered cystic fibrosis in vitro bronchial epithelial secretome. Am J Respir Cell Mol Biol. 2015; 53:22-32.

3. Costa C, Traves SL, Tudhope SJ, Fenwick PS, Belchamber KB, Russell RE, Barnes PJ, Donnelly LE. Enhanced monocyte migration to CXCR3 and CCR5 chemokines in COPD. Eur Respir J. 2016; 47:1093-102.

4. DeKruyff RH, Yu S, Kim HY, Umetsu DT. Innate immunity in the lung regulates the development of asthma. Immunol Rev. 2014; 260:235-48.

5. Rotta Detto Loria J, Rohmann K, Droemann D, Kujath P, Rupp J, Goldmann T, Dalhoff K. Nontypeable Haemophilus Influenzae infection upregulates the NLRP3 inflammasome and leads to caspase-1-dependent secretion of interleukin1 beta - a possible pathway of exacerbations in COPD. PLoS One. 2013; 8:e66818.

6. Neyt K, GeurtsvanKessel CH, Deswarte K, Hammad H, Lambrecht BN. Early IL-1 signaling promotes iBALT induction after influenza virus infection. Front Immunol. 2016; 7: 312.

7. Koyama S, Sato E, Masubuchi T, Takamizawa A, Kubo K, Nagai S, Isumi T. Procaterol inhibits IL-1beta- and TNFalpha-mediated epithelial cell eosinophil chemotactic activity. Eur Respir J. 1999; 14:767-75.

8. Martin RA, Ather JL, Lundblad LK, Suratt BT, Boyson JE, Budd RC, Alcorn JF, Flavell RA, Eisenbarth SC, Poynter ME. Interleukin-1 receptor and caspase-1 are required for the Th17 response in nitrogen dioxide-promoted allergic airway disease. Am J Respir Cell Mol Biol. 2013; 48:655-64.

9. Malek HA, Saleh DM. Cyclooxygenase-2 inhibitor celecoxib in a rat model of hindlimb ischemia reperfusion. Can J Physiol Pharmacol. 2009; 87:353-9.

10. Choo-Wing R, Syed MA, Harijith A, Bowen B, Pryhuber G, Janer C, Andersson S, Homer RJ, Bhandari V. Hyperoxia and interferon-gamma-induced injury in developing lungs occur via cyclooxygenase- 2 and the endoplasmic reticulum stress-dependent pathway. Am J Respir Cell Mol Biol. 2013; 48:749-57.

11. Torres MJ, Barrionuevo E, Kowalski M, Blanca M. Hypersensitivity reactions to nonsteroidal anti-inflammatory drugs. Immunol Allergy Clin North Am. 2014; 34:507-24, vii-viii.

12. Perez-Alzate D, Blanca-Lopez N, Dona I, Agundez JA, Garcia-Martin E, Cornejo-Garcia JA, Perkins JR, Blanca M, Canto G. Asthma and rhinitis induced by selective immediate reactions to paracetamol and non-steroidal anti-inflammatory drugs in aspirin tolerant subjects. Front Pharmacol. 2016; 7:215. 
13. Morales DR, Lipworth BJ, Guthrie B, Jackson C, Donnan PT, Santiago VH. Safety risks for patients with aspirinexacerbated respiratory disease after acute exposure to selective nonsteroidal anti-inflammatory drugs and COX2 inhibitors: Meta-analysis of controlled clinical trials. J Allergy Clin Immunol. 2014; 134:40-5.

14. Mastalerz L, Sanak M, Gawlewicz-Mroczka A, Gielicz A, Cmiel A, Szczeklik A. Prostaglandin E2 systemic production in patients with asthma with and without aspirin hypersensitivity. Thorax. 2008; 63:27-34.

15. Fritzsching B, Zhou-Suckow Z, Trojanek JB, Schubert SC, Schatterny J, Hirtz S, Agrawal R, Muley T, Kahn N, Sticht C, Gunkel N, Welte T, Randell SH, et al. Hypoxic epithelial necrosis triggers neutrophilic inflammation via IL-1 receptor signaling in cystic fibrosis lung disease. Am J Respir Crit Care Med. 2015; 191:902-13.

16. Kato K, Lillehoj EP, Kim KC. MUC1 regulates epithelial inflammation and apoptosis by PolyI:C through inhibition of Toll/IL-1 receptor-domain-containing adapter-inducing IFN-beta (TRIF) recruitment to Toll-like receptor 3. Am J Respir Cell Mol Biol. 2014; 51:446-54.

17. Joh EH, Gu W, Kim DH. Echinocystic acid ameliorates lung inflammation in mice and alveolar macrophages by inhibiting the binding of LPS to TLR4 in NF- $\kappa \mathrm{B}$ and MAPK pathways. Biochem Pharmacol. 2012; 84:331-40.

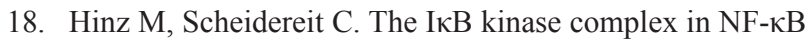
regulation and beyond. EMBO Rep. 2014; 15:46-61.

19. Cargnello M, Roux PP. Activation and function of the MAPKs and their substrates, the MAPK-activated protein kinases. Microbiol Mol Biol Rev. 2011; 75:50-83.

20. Liou CJ, Lai YR, Chen YL, Chang YH, Li ZY, Huang WC. Matrine attenuates COX-2 and ICAM-1 expressions in human lung epithelial cells and prevents acute lung injury in LPS-induced mice. Mediators Inflamm. 2016; 2016: 3630485 .

21. Suzukawa M, Koketsu R, Baba S, Igarashi S, Nagase H, Yamaguchi M, Matsutani N, Kawamura M, Shoji S, Hebisawa A, Ohta K. Leptin enhances ICAM-1 expression, induces migration and cytokine synthesis, and prolongs survival of human airway epithelial cells. Am J Physiol Lung Cell Mol Physiol. 2015; 309: L801-11.

22. Pauwels NS, Bracke KR, Dupont LL, Van Pottelberge GR, Provoost S, Vanden Berghe T, Vandenabeele P, Lambrecht BN, Joos GF, Brusselle GG. Role of IL-1 $\alpha$ and the Nlrp3/caspase-1/IL-1 $\beta$ axis in cigarette smoke-induced pulmonary inflammation and COPD. Eur Respir J. 2011; 38:1019-28.

23. Karmakar M, Katsnelson M, Malak HA, Greene NG, Howell SJ, Hise AG, Camilli A, Kadioglu A, Dubyak GR, Pearlman E. Neutrophil IL-1beta processing induced by pneumolysin is mediated by the NLRP3/ASC inflammasome and caspase- 1 activation and is dependent on K+ efflux. J Immunol. 2015; 194:1763-75.
24. dos Santos G, Kutuzov MA, Ridge KM. The inflammasome in lung diseases. Am J Physiol Lung Cell Mol Physiol. 2012; 303: L627-33.

25. Fu JJ, McDonald VM, Baines KJ, Gibson PG. Airway IL-1 beta and systemic inflammation as predictors of future exacerbation risk in asthma and COPD. Chest. 2015; 148:618-29.

26. Kim HY, Lee HJ, Chang YJ, Pichavant M, Shore SA, Fitzgerald KA, Iwakura Y, Israel E, Bolger K, Faul J, DeKruyff RH, Umetsu DT. Interleukin-17-producing innate lymphoid cells and the NLRP3 inflammasome facilitate obesity-associated airway hyperreactivity. Nat Med. 2014; 20:54-61.

27. Guo B, Fu S, Zhang J, Liu B, Li Z. Targeting inflammasome/ IL-1 pathways for cancer immunotherapy. Sci Rep. 2016; 6: 36107.

28. Koh DJ, Ahn HS, Chung HS, Lee H, Kim Y, Lee JY, Kim DG, Hong M, Shin M, Bae H. Inhibitory effects of casticin on migration of eosinophil and expression of chemokines and adhesion molecules in A549 lung epithelial cells via NF- $\mathrm{kB}$ inactivation. J Ethnopharmacol. 2011; 136:399-405.

29. Ye Q, Zhang QY, Zheng CJ, Wang Y, Qin LP. Casticin, a flavonoid isolated from Vitex rotundifolia, inhibits prolactin release in vivo and in vitro. Acta Pharmacol Sin. 2010; $31: 1564-8$.

30. Liou CJ, Len WB, Wu SJ, Lin CF, Wu XL, Huang WC. Casticin inhibits COX-2 and iNOS expression via suppression of NF-kappaB and MAPK signaling in lipopolysaccharide-stimulated mouse macrophages. J Ethnopharmacol. 2014; 158 Pt A:310-6.

31. Hernandez ML, Mills K, Almond M, Todoric K, Aleman MM, Zhang H, Zhou H, Peden DB. IL-1 receptor antagonist reduces endotoxin-induced airway inflammation in healthy volunteers. J Allergy Clin Immunol. 2015; 135:379-85.

32. Rasul A, Zhao BJ, Liu J, Liu B, Sun JX, Li J, Li XM. Molecular mechanisms of casticin action: an update on its antitumor functions. Asian Pac J Cancer Prev. 2014; 15:9049-58.

33. Shiue YW, Lu CC, Hsiao YP, Liao CL, Lin JP, Lai KC, Yu CC, Huang YP, Ho HC, Chung JG. Casticin induced apoptosis in A375.S2 human melanoma cells through the inhibition of NF- $\mathrm{kB}$ and mitochondria-dependent pathways in vitro and inhibited human melanoma xenografts in a mouse model in vivo. Am J Chin Med. 2016; 44:637-61.

34. Qu L, Liu FX, Cao XC, Xiao Q, Yang X, Ren KQ. Activation of the apoptosis signal-regulating kinase 1/c-Jun $\mathrm{N}$-terminal kinase pathway is involved in the casticininduced apoptosis of colon cancer cells. Exp Ther Med. 2014; 8:1494-500.

35. He M, Cao XC, He GC, Sheng XF, Ai XH, Wu YH. Casticin inhibits epithelial-mesenchymal transition of liver cancer stem cells of the SMMC-7721 cell line through downregulating Twist. Oncol Lett. 2014; 7:1625-31. 
36. He G, Cao X, He M, Sheng X, Wu Y, Ai X. Casticin inhibits self-renewal of liver cancer stem cells from the MHCC97 cell line. Oncol Lett. 2014; 7:2023-8.

37. Lee H, Jung KH, Park S, Choi W, Bae H. Casticin, an active compound isolated from Vitex Fructus, ameliorates the cigarette smoke-induced acute lung inflammatory response in a murine model. Int Immunopharmacol. 2015; 28:1097-101.

38. Gong J, Wu ZY, Qi H, Chen L, Li HB, Li B, Yao CY, Wang YX, Wu J, Yuan SY, Yao SL, Shang Y. Maresin 1 mitigates LPSinduced acute lung injury in mice. Br J Pharmacol. 2014; 171:3539-50.

39. Butt Y, Kurdowska A, Allen TC. Acute lung injury: a clinical and molecular review. Arch Pathol Lab Med. 2016; 140:345-50.

40. Gasse P, Riteau N, Vacher R, Michel ML, Fautrel A, di Padova F, Fick L, Charron S, Lagente V, Eberl G, Le Bert M, Quesniaux VF, Huaux F, et al. IL-1 and IL-23 mediate early IL-17A production in pulmonary inflammation leading to late fibrosis. PLoS One. 2011; 6: e23185.

41. Karmakar M, Katsnelson MA, Dubyak GR, Pearlman E. Neutrophil P2X7 receptors mediate NLRP3 inflammasomedependent IL-1beta secretion in response to ATP. Nat Commun. 2016; 7: 10555.

42. Duong KM, Arikkatt J, Ullah MA, Lynch JP, Zhang V, Atkinson K, Sly PD, Phipps S. Immunomodulation of airway epithelium cell activation by mesenchymal stromal cells ameliorates house dust mite-induced airway inflammation in mice. Am J Respir Cell Mol Biol. 2015; 53:615-24.

43. Yi H, Cho HJ, Cho SM, Jo K, Park JA, Kim NH, Amidon GL, Kim JS, Shin HC. Blockade of interleukin-6 receptor suppresses the proliferation of H460 lung cancer stem cells. Int J Oncol. 2012; 41:310-6.

44. Lee IT, Yang CM. Inflammatory signalings involved in airway and pulmonary diseases. Mediators Inflamm. 2013; 2013: 791231.

45. Huang WC, Tu RS, Chen YL, Tsai YY, Lin CF, Liou CJ. Conjugated linoleic acids suppress inflammatory response and ICAM-1 expression through inhibition of NF-kappaB and MAPK signaling in human bronchial epithelial cells. Food Funct. 2016; 7:2025-33.

46. Huang WC, Wu SJ, Tu RS, Lai YR, Liou CJ. Phloretin inhibits interleukin-1beta-induced COX-2 and ICAM-1 expression through inhibition of MAPK, Akt, and NFkappaB signaling in human lung epithelial cells. Food Funct. 2015; 6:1960-7.

47. Kim HS, Kim MJ, Kim EJ, Yang Y, Lee MS, Lim JS. Berberine-induced AMPK activation inhibits the metastatic potential of melanoma cells via reduction of ERK activity and COX-2 protein expression. Biochem Pharmacol. 2012; 83:385-94.
48. Chunhua M, Long H, Zhu W, Liu Z, Jie R, Zhang Y, Wang Y. Betulin inhibited cigarette smoke-induced COPD in mice. Biomed Pharmacother. 2016.

49. Duan MC, Zhang JQ, Liang Y, Liu GN, Xiao J, Tang HJ. Infiltration of IL-17-producing $\mathrm{T}$ cells and Treg cells in a mouse model of smoke-induced emphysema. Inflammation. 2016; 39:1334-44.

50. Gauvreau GM, El-Gammal AI, O'Byrne PM. Allergeninduced airway responses. Eur Respir J. 2015; 46:819-31.

51. Stanke F. The Contribution of the airway epithelial cell to host defense. Mediators Inflamm. 2015; 2015: 463016.

52. Whitsett JA, Alenghat T. Respiratory epithelial cells orchestrate pulmonary innate immunity. Nat Immunol. $2015 ; 16: 27-35$.

53. Li T, Zhong J, Dong X, Xiu P, Wang F, Wei H, Wang X, Xu Z, Liu F, Sun X, Li J. Meloxicam suppresses hepatocellular carcinoma cell proliferation and migration by targeting COX-2/PGE2-regulated activation of the beta-catenin signaling pathway. Oncol Rep. 2016; 35:3614-22.

54. Rossol M, Heine H, Meusch U, Quandt D, Klein C, Sweet MJ, Hauschildt S. LPS-induced cytokine production in human monocytes and macrophages. Crit Rev Immunol. 2011; 31:379-446.

55. Staples KJ, Hinks TS, Ward JA, Gunn V, Smith C, Djukanovic R. Phenotypic characterization of lung macrophages in asthmatic patients: overexpression of CCL17. J Allergy Clin Immunol. 2012; 130:1404-12 e7.

56. Bonner K, Pease JE, Corrigan CJ, Clark P, Kay AB. CCL17/ thymus and activation-regulated chemokine induces calcitonin gene-related peptide in human airway epithelial cells through CCR4. J Allergy Clin Immunol. 2013; 132:942-50 e1-3.

57. Seo GS, Jiang WY, Park PH, Sohn DH, Cheon JH, Lee SH. Hirsutenone reduces deterioration of tight junction proteins through EGFR/Akt and ERK1/2 pathway both converging to HO-1 induction. Biochem Pharmacol. 2014; 90:115-25.

58. Yan C, Wang X, Cao J, Wu M, Gao H. CCAAT/enhancerbinding protein $\gamma$ is a critical regulator of IL-1 $\beta$-induced IL-6 production in alveolar epithelial cells. PLoS One. 2012; 7: e35492.

59. Ballinger MN, Newstead MW, Zeng X, Bhan U, Mo XM, Kunkel SL, Moore BB, Flavell R, Christman JW, Standiford TJ. IRAK-M promotes alternative macrophage activation and fibroproliferation in bleomycin-induced lung injury. J Immunol. 2015; 194:1894-904.

60. Huang WC, Fang LW, Liou CJ. Phloretin attenuates allergic airway inflammation and oxidative stress in asthmatic mice. Front Immunol. 2017; 8:134. 